\title{
Improving Grade 4 Student Speaking Skills in Indonesian Language Lessons through Problem Based Learning Model
}

\author{
Nanik Yuni Setyowati \\ SD Al Isyad AI Islamiyyah 01 Purwokerto \\ tsamaraalesha@gmail.com
}

\section{Article History}

accepted 01/11/2020

approved 08/11/2020

published $15 / 11 / 2020$

\begin{abstract}
The purpose of this research is to improve the speaking skills of grade 4 students in Indonesian language lessons through the Problem Based Learning Model. This research is a classroom action research (PTK) which is carried out in three cycles, each cycle consisting of planning, implementation, observation, and reflection stages. The subjects of this study were the fourth grade students of SD Al Irsyad Al Islamiyyah 01 Purwokerto in the academic year 2020/2021, totaling 22 students. Data collection techniques using observation and tests. Data analysis includes data presentation, and drawing conclusions. Research shows that the application of the Problem Based Learning Model method can improve students' speaking skills in the material of extracting information from a character through interviews using a list of questions in class IV SD Al Irsyad Al Islamiyyah 01 Purwokerto academic year 2020/2021 as evidenced by the percentage of completeness of speaking skills in the cycle I was $68.5 \%$, cycle 2 was $91 \%$ and cycle 3 increased to $95 \%$.
\end{abstract}

Kata kunci: Speaking skills, problem based learning, students

Abstrak

Tujuan penelitian ini adalah Peningkatan Keterampilan Berbicara Siswa Kelas 4 pada Pelajaran Bahasa Indonesia Melalui Model Problem Based Learning. Penelitian ini merupakan penelitian tindakan kelas (PTK) yang dilaksanakan dalam tiga siklus, setiap siklus terdiri dari tahap perencanaan, pelaksanaan, observasi, dan refleksi. Subjek penelitian ini adalah siswa kelas IV SD AI Irsyad AI Islamiyyah 01 Purwokerto tahun pelajaran 2020/2021 yang berjumlah 22 siswa. Teknik pengumpulan data menggunakan observasi dan tes. Analisis data meliputi penyajian data, dan penarikan kesimpulan. Penelitian menunjukkan bahwa penerapan metode Model Problem Based Learning dapat meningkatkan keterampilan berbicara siswa pada materi menggali informasi dari seorang tokoh melalui wawancara menggunakan daftar pertanyaan di kelas IV SD AI Irsyad Al Islamiyyah 01 Purwokerto tahun pelajaran 2020/2021 yang dibuktikan dengan persentase ketuntasan keterampilan berbicara pada siklus I sebesar $68.5 \%$, siklus 2 sebesar $91 \%$ dan pada siklus 3 meningkat menjadi 95\%. Kata kunci: Keterampilan berbicara, problem based learning, siswa

p-ISSN 2620-9284

e-ISSN 2620-9292

This work is licensed under a Creative Commons Attribution-ShareAlike 4.0 International License. 


\section{PENDAHULUAN}

Bahasa sebagai ilmu dasar memiliki peranan yang sangat penting dalam mencapai keberhasilan kemampuan berkomunikasi. Bahasa Indonesia sebagai salah satu mata pelajaran yang diajarkan di bangku sekolah, juga terus relevan dengan perubahan peradaban manusia yang berkembang sangat pesat. Mata pealajaran Bahasa Indonesia di tingkat Sekolah Dasar mempunyai peranan penting dalam membangun kemampuan dasar berkomunikasi seorang murid dan akan dikembangkan pada tingkat dan jenjang sekolah yang lebih tinggi

Komunikasi dalam mata pelajaran Bahasa Indonesia merupakan komponen penting yang harus dikembangkan. Kemamupuan berkomunikasi ini diperoleh dengan tidak mudah. Kemampuan berkomunikasi sesorang siswa diperoleh tidak serta. Salah satu komponen Bahasa Indonesia yang harus dikuasai oleh siswa adalah berbicara, sebab keterampilan berbicara menunjang keterampilan lainnya

Keterampilan berbicara adalah kemampuan untuk mengungkapkan gagasan kepada pihak lain secara lisan. Dalam pembelajaran keterampilan berbicara ini terdapat empat hal yang perlu menjadi perhatian bagi seorang guru sebelum mendesain dan melaksanakan proses pembelajaran, yaitu: 1) Pemberian (feedback) dalam pembelajaran berbicara, Materi Pembelajaran Berbicara, 3) Penilaian dalam pembelajaran berbicara, Model-model pembelajaran berbicara. (Kundharu Saddono, St. Y. Slamet, 2014)

Siswa yang mempunyai keterampilan berbicara yang baik, alur pembicaraannya akan lebih mudah dipahami oleh lawan bicara atau penyimaknya. Kemampuan berbicara yang baik yang dimiliki oleh siswa juga akan sangat menunjang dalam kemampuan menyimak dan memahami suatu bacaan. Akan tetapi, masalah yang terjadi di lapangan adalah tidak semua peserta mempunyai kemampuan berbicara yang baik. Oleh sebab itu, pembinaan keterampilan berbicara harus dilakukan sedini mungkin.

Berdasarkan pengamatan pada siswa kelas IV SD Al Irsyad Al Islamiyyah 01 Purwokerto, Permasalahan bagi peserta ddik yang ditemui dalam kegiatan belajar mengajar Bahasa Indonesia secara daring pada masa pandemi covid - 19 ini adalah, terbatasnya kesempatan bagi siswa untuk mengasah kemampuan dan berkomunikasinya secara intensif, sehingga kemampuan dan kemampuan berkomunikasinya kurang berkembang. Cara pengajaran yang monoton dan konvensional dianggap kurang menarik dan tidak efektif dalam menarik minat belajar siswa. Model pembelajaran yang interaktif dapat membangkitkan motivasi, minat atau gairah belajar siswa, serta dapat memberikan kesempatan bagi siswa untuk memberikan tanggapannya terhadap materi yang disampaikan.

Adanya beberapa permasalahan yang terlihat di kelas IV SD AI Irsyad AI Islamiyyah 01 Purwokerto tersebut memerlukan sebuah solusi yaitu dengan mengadakan sebuah penelitian tindakan kelas yang diharapkan dapat mengatasi permasalahan yang timbul. Berdasarkan identifikasi permasalahan yang telah dilakukan, peneliti melakukan refleksi mengenai permasalahan yang dianggap paling penting dan harus segera diatasi yaitu masih banyak siswa yang belum memahami konsep materi wawancara sehingga menyebabkan keterampilan berbicara siswa menjadi rendah, terbukti dengan banyaknya siswa yang mempunyai nilai di bawah KKM (75). Oleh sebab itu, peneliti memilih model pembelajaran Problem Based Learning (PBL) sebagai pilihan tindakan yang diharapkan mampu membantu siswa dalam memahami konsep wawancara.

Pembelajaran dengan model Problem Based Learning ini cukup efektif dalam meningkatkan aktivitas dan hasil belajar. Hal ini dapat dilihat dari beberapa jurnal yang menyatakan bahwa model ini cukup efektif. Kurnia Norma Hidayani (2015) menyatakan bahwa penerapan model Problem Based Learning pada pembelajaran IPS terbukti 
dapat meningkatkan aktivitas siswa, aktivitas guru dan hasil belajar siswa kelas IIS 3 SMA Negeri 1 Bae

Tujuan melakukan penelitian dengan judul Peningkatan Keterampilan Berbicara pada Pelajaran Bahasa Indonesia Melalui Model Problem Based Learning berbantuan Video pada siswa kelas 4 SD Al Irsyad Al Islamiyyah 01 Purwokerto adalah meningkatkan keterampilan berbicara pada pelajaran Bahasa Indonesia materi tentang wawancara.

\section{METODE}

Penelitian ini merupakan penelitian tindakan kelas (PTK) kolaboratif yang dilaksanakan dalam tiga siklus, setiap siklus terdiri dari tahap perencanaan, pelaksanaan, observasi, dan refleksi. Subjek penelitian ini adalah siswa kelas IV SD AI Irsyad AI ISlamiyyah 01 Purwokerto tahun pelajaran 2020/2021 yang berjumlah 32 peserta.

Data yang dianalisis berupa data kualitatif yaitu penggunaan Problem based learning dan data kuantitatif yaitu hasil keterampilan berbicara siswa. Teknik pengumpulan data menggunakan observasi dan tes. Uji validitas data menggunakan triangulasi teknik dan triangulasi sumber. Analisis data meliputi penyajian data, dan penarikan kesimpulan

\section{HASIL DAN PEMBAHASAN}

Berdasarkan analisis hasil penelitian yang telah diuraikan maka pembahasan pada penelitian ini sebagai berikut.

1. Penerapan model Problem Based Learning

Hasil penelitian menunjukkan peningkatan penerapan metode Problem Based Learning yang dilakukan oleh guru. Terlihat pada tabel berikut.

Tabel 1. Peningkatan penerapan Model Problem Based Learning

\begin{tabular}{llccc}
\hline \multirow{2}{*}{ No } & \multirow{2}{*}{ Langkah } & \multicolumn{3}{c}{ Rata-rata } \\
\cline { 3 - 5 } & & $\begin{array}{c}\text { Siklus } \\
1\end{array}$ & $\begin{array}{c}\text { Siklus } \\
2\end{array}$ & $\begin{array}{c}\text { Siklus } \\
3\end{array}$ \\
\hline 1 & Orientasi siswa kepada masalah & 2,5 & 3,5 & 4 \\
\hline 2 & Mengorganisasikan siswa untuk belajar & 3 & 3 & 3,5 \\
\hline 3 & Membantu penyelidikan mandiri dan kelompok & 4 & 4 & 4 \\
\hline 4 & Mengembangkan dan mempresentasikan hasil karya & 3 & 3 & 3 \\
\hline \multirow{2}{*}{5} & $\begin{array}{l}\text { Menganalisis dan mengevaluasi proses pemecahan } \\
\text { masalah }\end{array}$ & 3 & 3 & 4 \\
\hline & Rata-rata & 3,1 & 3,3 & 3,7 \\
\hline & Persentase ketuntasan & $78 \%$ & $83 \%$ & $93 \%$ \\
\hline
\end{tabular}

Berdasarkan analisis hasil penelitian yang telah diuraikan maka penerapan model Problem Based Learning yang dilakukan oleh guru mengalami peningkatan, pada siklus I persentase ketuntasan baru mencapai $78 \%$, sedangkan pada Siklus 2 mengalami peningkatan sebesar $83 \%$. Setelah siklus 3 persentase meningkat lagi menjadi $93 \%$. Hal ini menunjukkan bahwa guru sudah terbiasa menggunakan model pembelajaran Problem Based Learning. Adapun Langkah-langkah Problem Based Learning menurut Rusmono (2014: 243) adalah: 
1. Orietasi siswa kepada masalah

Pada kegiatan ini guru menjelaskan tujuan pembelajaran, memotivasi siswa yang terlibat pada aktivitas pemecahan masalah. Guru memberikan masalah kepada anak berdasarkan materi yang diajarkan

2. Mengorganisasikan siswa untuk belajar

Guru mengorganisasi dalam beberapa kelompok untuk melakukan diskusi dalam penyelesaian masalah

3. Membantu penyelidikan mandiri dan kelompok

Guru mendorong siswa untuk mengumpulkan informasi yang sesuai untuk mendapatkan penjelasan dan pemecahan masalah

4. Mengembangkan dan mempresentasikan hasil karya

Guru membantu siswa dalam merencanakan dan menyiapkan karya

5. Menganalisis dan mengevaluasi proses pemecahan masalah

Guru membantu siswa untuk melakukan evaluasi terhadap penyelidikan siswa

Menurut Mustamilah (2015:3) Model Pembelajaran Problem Based Learning $(P B L)$ adalah pembelajaran yang memberikan masalah kepada siswa dan siswa diharapkan dapat menyelesaikan masalah yang diberikan dengan pembelajaran yang aktif. Sehingga pembelajaran yang berlangsung guru hanya fasilitator dan siswa aktif dalam pembelajaran.

2. Hasil keterampilan berbicara

Hasil penelitian menunjukkan peningkatan keterampilan berbicara pada siswa kelas 4 . Terlihat pada tabel berikut.

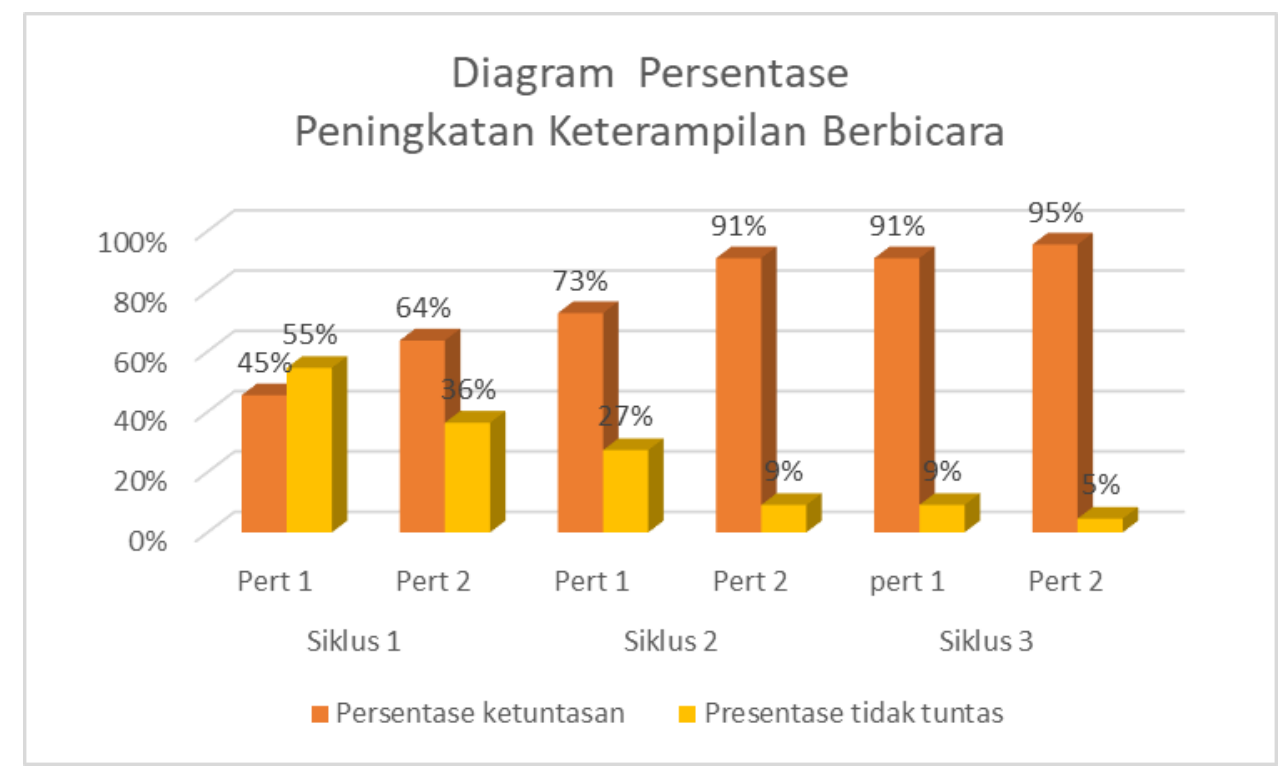

Gambar 1. Hasil keterampilan berbicara

Berdasarkan diagram diatas, pembelajaran menggunakan Problem based Learning pada pembelajaran Bahasa Indonesia dapat meningkatkan hasil keterampilan berbicara pada siswa di kelas IV SD Al Irsyad Al Islamiyyah 01 Purwokerto secara signifikan. Pada Siklus I pertemuan ke 1 siswa mengalami ketuntasan sebesar 55\%, setelah dilanjutkan pada pertemuan ke 2 siswa mengalami ketuntasan sebesar $64 \%$. Hal ini masuk belum maksimal. Kemudian dilanjutkan siklus ke 2.

Pada siklus ke 2 pertemua 1 siswa mengalami ketuntasan sebesar $73 \%$, sedangkan pada pertemuan ke 2 mengalami kenaikan ketuntasan menjadi $91 \%$. 
Untuk menguji validitas penelitian dilanjutkan siklus 3 . Pada siklus ke 3 pertemuan 1 ketuntasan hasil keterampilan berbicara mencapai $91 \%$ dan pada pertemuan ke 2 mengalami kenaikan 95\%. Hal ini menunjukkan bahwa penggunaan model pembelajaran Problem Based Learning dapat meningkatkan keterampilan berbicara siswa.

Penelitian ini juga diperkuat dengan adanya penelitian dari (Setyaningrum, 2018) yang berjudul Peningkatan hasil belajar menggunakan model problem based learning (PBL) pada siswa kelas $5 \mathrm{SD}$. PBL dapat meningkatkan hasil belajar siswa sebesar $89 \%$, yaitu hasil belajar terutama pada muatan pelajaran PPKn dan IPS pada tema 1 subtema 1 siswa kelas 5 SD Negeri Salatiga Hal ini juga selaras denga penelitian Rosa (2018), Penerapan model problem based learning dapat Meningkatkan motivasi dan prestasi belajar ekonomi Siswa Kelas XI IPS 4 SMA Negeri 1 Sedayu sebesar $88 \%$

Model Problem Based Learning (PBL) membuat siswa dapat lebih aktif berpartisipasi dalam proses pembelajaran yang sedang berlangsung siswa mendapatkan pengalaman untuk memecahkan masalah serta mencari solusi dari masalah tersebut, siswa menjadi lebih bertanggung jawab pada proses pembelajaran berlangsung. Karena pada penerapan model pembelajaran Problem Based Learning (PBL) siswa memecahkan masalah yang terjadi nyata dikehidupan sehari-hari, ini berdampak pada keaktifan siswa yang ingin mencari tahu jawabannya. Hal ini perkuat oleh penelitian yang dilakukan oleh Guntara (2014:2) yang berjudul Hasil Belajar Siswa Pada Materi Panjang Garis Singgung Persekutuan Dua pembelajaran Problem Based Learning $(\mathrm{PBL})$ dapat meningkatkan hasil belajar dengan menentukan garis singgung dan dapat menyelesaikan soal yang telah diberikan. Pembelajaran dengan menggunakan model pembelajaran Problem Based Learning (PBL) menjadikan siswa lebih bertanggung jawab terhadap kelompok serta lebih percaya diri, siswa dapat bekerja sama dengan baik di dalam kelompok. Pembelajaran PBL memiiki kelebihan seperti yang diungkapkan oleh (Wulandari B. H., 2013) pemecahan yang baik untuk memahami isi pelajaran, pemecahan masalah menantang kemampuan siswa, membantu proses transfer siswa untuk memahami masalah dalam kehidupan seharihari,merangsang siswa untuk belajar kontinu.

\section{SIMPULAN}

Berdasarkan hasil penelitian tindakan kelas yang telah dilakukan peneliti melalui penggunaan metode problem based learning pada mata pelajaran Bahasa Indonesia dapat disimpulkan sebagai berikut:

1. Penerapan metode problem based learning pada mata pelajaran untuk meningkatkan keterampilan berbicara peserta didik kelas berjalan dengan baik.

2. Keterampilan berbicara peserta didik metode problem based learning berbantuan video pada mata pelajaran Bahasa Indonesia pada peserta didik kelas 4 SD Al Irsyad Al Islamiyyah 01 Purwokerto mengalami peningkatan. Siklus 1 ketuntasan keterampilan berbicara peserta didik adalah 64\% (rendah). Hasil tersebut menunjukkan bahwa pada siklus I peserta didik belum memenuhi kriteria prosentase ketuntasan keterampilan berbicara peserta didik yang ditentukan. Hal tersebut mendorong peneliti untuk melakukan perbaikan pada siklus 2 dan siklus 3, prosentase ketuntasan keterampilan menjadi 95\% (sangat baik).

Berdasarkan simpulan di atas, maka peneliti memberikan saran-saran sebagai berikut: 
1. Bagi Sekolah, sebagai bahan masukan bagi sekolah dalam melaksanakan pembelajaran khususnya pembelajaran bahasa Indonesia untuk meningkatkan kemampuan berbicara dengan metod.e problem based learning berbantuan video

2. Bagi Guru, guru dalam mengajar hendaknya meningkatkan kemampuan ITnya sehingga pembelajaran lebih menarik.

3. Bagi Peserta didik:

a. Hendaknya lebih mengembangkan inisiatif dan keberanian dalam menyampaikan pendapat dalam proses pembelajaran untuk menambah pengetahuan sehingga dapat meningkatkan prestasi belajar.

b. Hendaknya ikut berperan aktif dalam proses pembelajaran dan rajin belajar sehingga dapat memperoleh hasil belajar yang optimal.

\section{DAFTAR PUSTAKA}

Guntara, Suarja dan Nanci. (2014). Penerapan Model Problem Based Learning Untuk Meningkatkan Kemampuan Pemecahan Masalah Matematika Siswa Kelas 5 SD. Jurnal Mimbar PGSD Universitas Pendidikan Ganesha, 2 (1) 2

Kundaru Saddono, St. Y. Slamet, Pembelajaran Keterampilan Berbahasa Indonesia, (Yogyakarta: Graha IImu, 2014) cetakan 2

Mustamilah. (2015). Peningkatan Keterampilan Proses Pemecahan masalah dan Hasil Belajar Mengguanakan Model Problem Based Learning Pada Sub Tema Merawat Tubuhku Siswa Kelas 1 SD Negeri 1 Gosono- Wonosegoro. Scholaria, 5 (1) 3

Norma, Kurnia, Hidayani. 2015. Peningkatan Kemampuan Analisis Masalah Ekonomi Dengan Model Pembelajaran Problem Based Learning. Semarang:UNNES Press.

Rusmono. 2014. Strategi Pembelajaran dengan Problem Based Learning Itu Perlu.

Bogor: Ghalia Indonesia

Rosa Delima Istiningtyas, Rosa. 2018. Skripsi. Penerapan Model Problem Based Learning untuk Meningkatkan Motivasi dan Prestasi Belajar Ekonomi Siswa Kelas XI IPS 4 SMA Negeri 1 Sedayu UNY.Yogyakarta

Setiyaningrum, Monika. 2018. Peningkatan hasil belajar menggunakan model problem based Learning (PBL) pada siswa kelas 5 SD.Jurtika, 1(2)

Wulandari, Bekti dan Herman Dwi Surjono. Pengaruh Problem Based Learning Terhadap Hasil Belajar Ditinjau Dari Motivasi Belajar PLC Di SMK. Jurnal Pendidikan Vokasi. 3 (2) 4 